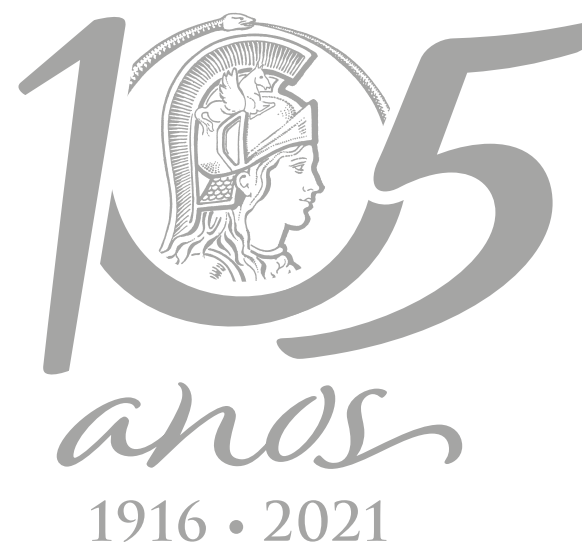

\title{
Artisanal fishers' local ecological knowledge and attitudes toward conservation about the shrimp (Xiphopenaeus kroyeri) on the Brazilian central coast
}

\author{
JOELSON MUSIELLO-FERNANDES, CAMILAH A. ZAPPES, HEITOR O. BRAGA \& \\ MAURICIO HOSTIM-SILVA
}

\begin{abstract}
In order to contribute to the management of small-scale trawling fishing of the Xiphopenaeus kroyeri shrimp, the aim of this study was to evaluate the local ecological knowledge (LEK) and the conservationist attitudes of artisanal fishers in four fishing communities along the central Brazilian coast. This study was based on 80 ethnographic interviews conducted in two communities are in the state of Bahia (Santa Cruz Cabrália and Barra de Caravelas) and two communities in the state of Espírito Santo (Barra Nova and Anchieta). The fishers present knowledge compliance with literature, except in aspects reproductive of the shrimp and are willing to exchange knowledge with researchers. The mean attitude index of the fishers was 0.65. Education activities should focus on the reproductive biology of shrimp to include fishing communities in the drafting of legislation about closed season period, as this issue is directly related to possible divergences between fishers do not adhere to them. The results suggest that, dialogue and knowledge exchange is necessary among the stakeholders, including the fishers, scientists and managers, who are responsible for the elaboration of management measures.
\end{abstract}

Key words: fisheries management, local ecological knowledge, trawling fishing, smallscale, fisheries.

\section{INTRODUCTION}

Small-scale (or artisanal) fisheries involve approximately 50 million people worldwide, being responsible for a significant portion of the economy mainly in tropical coastal regions (Berkes et al. 2001, FAO 2012, Watson 2017). In these regions, this fishing activity is socially important, as it is a vital source of subsistence, it involves food safety, and it is a way of life in fishing communities (Allison \& Ellis 2001, Batista et al. 2014).

This activity is carried out in developing countries and is considered complex because of the cultural diversity of the various communities that practice it and of the diversity of the fishery resources (Begossi 2006, Pauly 2006). Artisanal fisher may or may not use boats for the practice of the activity. These vessels are typically small, have little technological instrumentation, have a low range of use, and require little capital investment (Hawkins \& Roberts 2004). In this sense, the exploitation and success of fishing resources by artisanal fishers are not associated with the use of technological devices but rather with the empirical observations of abundance and the distribution of the resources (Pita et al. 2010, Deepananda et al. 2016). 
In this context, local ecological knowledge (LEK) emerges as a tool to help conserve and maintain artisanal fishing (Olsson \& Folke 2001, Begossi 2008). The LEK is derived from the accumulation of the experiences of the individuals in an environment, resulting from a long process of trial and error, with knowledge being orally transmitted between generations in the communities, thereby allowing the development of a culture integrated with nature (Berkes 1999, Olsson \& Folke 2001).

Historically, the management of fishing resources in small-scale fisheries in tropical regions has represented a challenge for scientists and fisheries managers (Mahon 1997, Oliveira et al. 2016). The same time, fishing communities are the first to notice declines in fish stocks (Silvano \& Begossi 2012, Finkbeiner 2015). Thus, the inclusion of LEK in fisheries management has been an effective and low-cost method for addressing the lack of scientific information, as well as for increasing government discussions, council formation, and participatory monitoring (Silvano \& Begossi 2012, Leite \& Gasalla 2013). This inclusion decentralizes the subject of government and institutional power and ensures greater representation of fishers in decision-making processes, with compromise, responsibility and empowerment of stakeholders in the management process (Berkes et al. 2001, Abreu et al. 2017, Araujo et al. 2017).

To achieve this scenario of collaborative management, studies investigating the conservation attitudes of stakeholders toward the management of fishery resources, effectiveness of marine protected areas (MPAs), and conservation of marine endangered species have increased in recent years (Hynes et al. 2014, Braga etal.2017,2018, Awabdi etal.2018). According to Milfont \& Duckitt (2010), the attitudes of the individual can be defined as a psychological tendency expressed in the evaluation of a natural environment that is somewhat either favorable to or disinclined toward conservation. In this sense, understanding the criteria that interfere with people's attitudes and behaviors in the exploitation of resources in the marine environment can contribute to the effectiveness of the management measures (Hoehn \& Thapa 2009, Tonin \& Lucaroni 2017).

Ecologically, penaeid shrimp play a key role in coastal food webs is important to the marine biota on tropical continental platforms (AbarcaArenas et al. 2007). The Xiphopenaeus kroyeri (Heller, 1862) shrimp belong of the Penaeidae family, with a wide distribution ranging from North Carolina in the United States to the south of Brazil (Costa et al. 2003). The species presents larger biomasses in shallow water (up to approximately $30 \mathrm{~m}$ deep). Its distribution and habits make it accessible to small-scale fishing, and it can be processed by families, making it one of the main resources of many fishing communities along the Brazilian coast (Graça-Lopes et al. 2007, Musiello-Fernandes et al. 2018).

The shrimp X. kroyeri since 2004 is part of the National List of Species of Aquatic Invertebrates and Fish Overexploited or Threatened with Overexploitation (MMA 2004, 2014). Due to its economic and social importance, aspects of $X$. kroyeri shrimp have been studied, such as its population structure, reproduction, ecology, and genetics (See Table I). On the other hand, studies on the species related to LEK of fishers are still scarce in the country, as well in area of distribution of this species (MusielloFernandes et al. 2017, Nascimento et al. 2018). Thus, shrimp trawling management considers only the biological aspects of the resource available in the literature, despite the evident importance of studies related to LEK for success in fisheries management (Foster \& Vincent 2010). Therefore, the objective of the present study 
Table I. Elements contained in the semi-structured interviews questionnaire applied to fishermen along the Brazilian central coast.

\begin{tabular}{|c|c|c|}
\hline Topics & Questions & $\begin{array}{l}\text { Number of } \\
\text { questions } \\
\text { (percentage of } \\
\text { questionnaire) }\end{array}$ \\
\hline 1. Profile of the interviewee & $\begin{array}{l}\text { - Age. } \\
\text { - Schooling. } \\
\text { - Fishing time in the region. } \\
\text { - If fisher has always fished for shrimp. }\end{array}$ & $4(15 \%)$ \\
\hline 2. LEK of fishermen & $\begin{array}{l}\text { - Popular name. } \\
\text { - Ecological description of habitat, maximum depth, } \\
\text { migration in population. } \\
\text { - Biological description of development: fast or slow } \\
\text { growth, whether they are eggs or larvae at some stage of } \\
\text { life, and whether the females carry eggs together/inside } \\
\text { the body. } \\
\text { - Biological description of longevity: how long does it live? } \\
\text { - Biological description of reproduction: when do they } \\
\text { reproduce? } \\
\text { - Ecological description of predators: which animals feed } \\
\text { on shrimp? } \\
\text { - Diet: what are the shrimp prey? }\end{array}$ & $12(46 \%)$ \\
\hline \multirow{2}{*}{$\begin{array}{l}\text { 3. Attitudes toward } \\
\text { conservation }\end{array}$} & $\begin{array}{l}\text { - Do you think it is necessary to stop shrimp fishing at } \\
\text { some period? } \\
\text { - Is it important to keep the marine environment clean? } \\
\text { - Must shrimp be preserved? } \\
\text { - Is there use for small shrimp? }\end{array}$ & \\
\hline & $\begin{array}{l}\text { - What do you do when you catch small shrimp? } \\
\text { - Is there a natural shrimp predator at sea? } \\
\text { - Is the closed season respected? What about the } \\
\text { minimum trawling depth? What mesh sizes do you use? } \\
\text { - What is the destination of the bycatch? }\end{array}$ & $10(39 \%)$ \\
\hline
\end{tabular}

was to evaluate the LEK and the conservationist attitudes of artisanal fishers of $X$. kroyeri shrimp in four fishing communities along the central Brazilian coast.

\section{MATERIALS AND METHODS}

\section{Study area}

The research was carried out with artisanal shrimp trawlers in four fishing communities located along the central Brazilian coast (Figure 1). Two communities were in the state of Bahia:

i) Santa Cruz Cabrália (16ำ16'S; 3910'W), with 


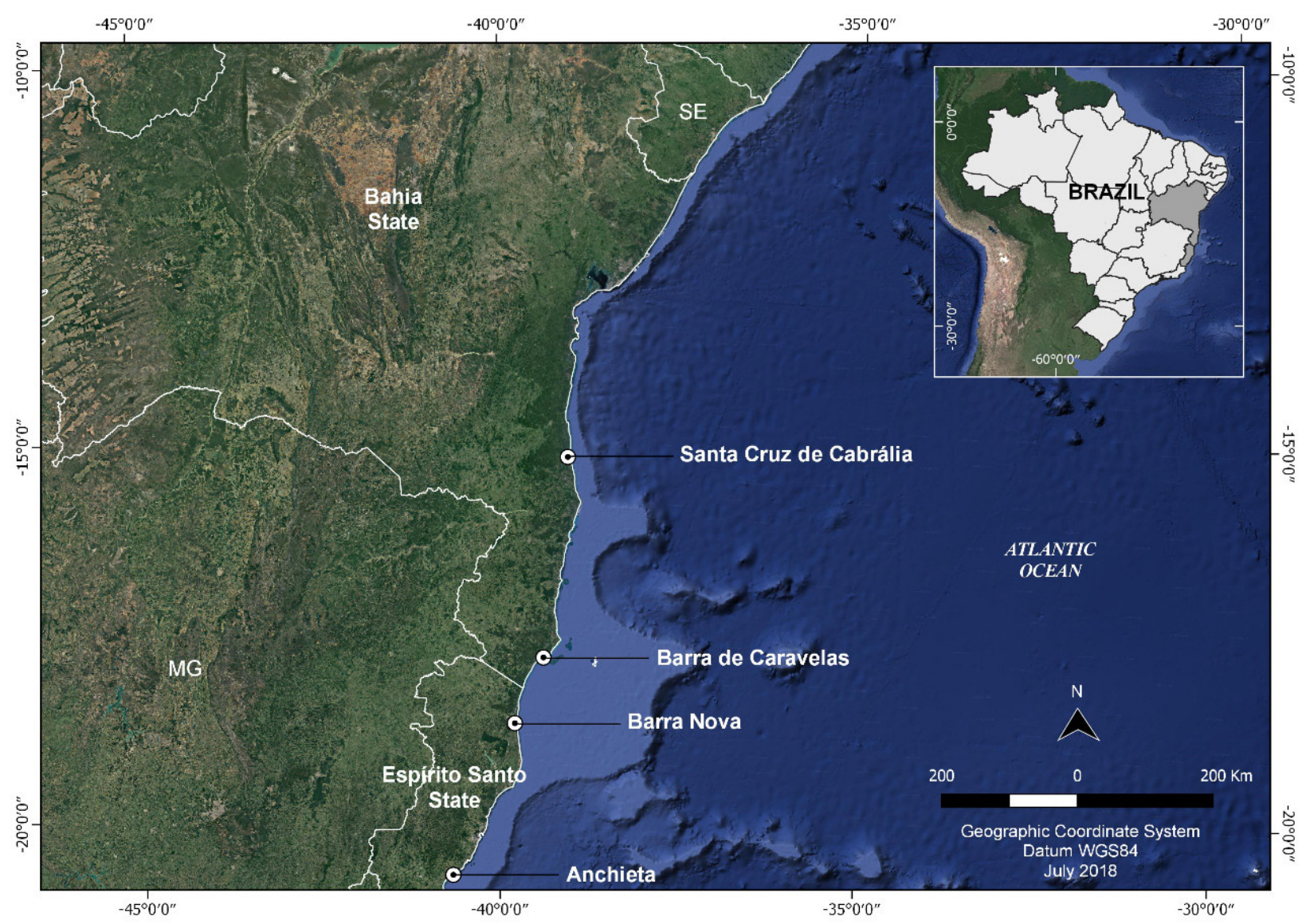

Figure 1. Map of the study area, highlighting the studied communities along the central Brazilian coast.

18 fisher registered in the Fisher's Colony Z-51 (according to the president of the colony); and ii) Barra de Caravelas ( $17^{\circ} 43^{\prime} \mathrm{S}$; $39^{\circ} 15^{\prime} \mathrm{W}$ ), which is inserted in the Cassurubá Extractivist Reserve, considered a priority for conservation, and had 60 fisher registered in the Fisher's Colony Z-25 (Leão et al. 2003, ICMBIO 2012, Viana et al. 2015). Additionally, there were two communities in the state of Espírito Santo: i) Barra Nova (1895'S; $39^{\circ} 74^{\prime} \mathrm{W}$ ), with 20 fishers registered in Fisher's Colony Z-13; and ii) Anchieta (2048'S; 403' W), with approximately 25 fishers registered in Fisher's Colony Z-4 (Carvalho et al. 2016).

\section{Data collection}

Between January and March 2016, data on the LEK of fishers and attitudes toward conservation of $X$. kroyeri shrimp were obtained through 80 ethnographic interviews from semi structured questionnaires with open and closed questions (Albuquerque et al. 2014), as follows: Barra de Caravelas $(n=36)$, Anchieta $(n=18)$, Barra Nova $(n=14)$, and Santa Cruz Cabrália $(n=12)$. The number of fishers interviewed was greater than $60 \%$ of the fisher who were active in the shrimp fishery in the communities, and this percentage is adequate for studies involving ethnographic methods and data (Mason 2010). In studies involving the human dimension, the frequencies are no more important than the meaning and deepening of the discourses of the stakeholders (Crouch \& McKenzie 2006).

This study was approved by the Ethics Committee of the Federal University of 
Espírito Santo (CAAE no. 80663317.0.0000.5542), Southeastern off Brazil. The objective of the study, along with the declaration of consent to participate (Statement of Informed Consent (IC)), was presented to the presidents of the fisher colonies and to the fisher participating in the research (Azevedo 2005).

Data collection was initiated by participant application, which allowed the researcher to establish contact with the subjects of the research, and this initial contact information was recorded in the field diary (Albuquerque et al. 2014, Malinowski 1978). A priori, a pilot test of the questionnaire was performed, and the interviews obtained in this test were discarded (White et al. 2005). All interviews occurred at the disembark sites and were conducted by the same researcher (JMF) to maximize the trust between the interviewee/interviewer and increase the reliability of the data (Opdenakker 2006). The choice of the first interviewee was made with the help of a local guide from each area (Albuquerque et al. 2010); the interview identified other fisher who could participate in the study using the snowball technique (Bailey 1982, Patton 1990). To minimize a possible trend in the data, this technique could be discontinued, and the next respondent could be randomly chosen (Albuquerque et al. 2014).

The interviews were guided by a questionnaire containing three main parts: i) profile of the fisher (age, schooling, time spent on shrimp fishing, and time as fisher in the region), corresponding to $15 \%$ of the questionnaire; ii) fisher LEK regarding X. kroyeri shrimp (folk name, habitat, longevity and growth, development, and reproduction), representing $46 \%$ of the questionnaire; and iii) attitudes toward the conservation of the shrimp (tendency of respondents classified as positive, moderate, and negative in relation to conservation of the shrimp resource), equivalent to $38 \%$ of the questionnaire (Table I). Attitudes were defined as a psychological tendency that is expressed by a person showing some degree of favor toward or disinclination toward the conservation of an environmental resource (Eagly \& Chaiken 1993, Milfont \& Duckitt 2010).

\section{Data analysis}

For data analysis, the triangulation method was used to link the information obtained through the ethnographic instruments (participant observation, field diary, and interview reports), and these data were later organized into categories following the order of the questionnaire (Yeasmin \& Rahman 2012). To establish comparisons between the fisher's LEK on shrimp and the biological data already published in scientific literature for the species, was developed a table of comparative cognition and was analyzed through an emic-etic approach (Harris 1976, Braga et al. 2018).

The data related to the conservation attitudes for the species the $X$. kroyeri shrimp were analyzed quantitatively. This analysis was performed using the likert scale with 3 points (Likert 1932). The attitudes toward conservation of the Atlantic seabob shrimp, the scores were as follows: "favorable" = 1 point, "moderate" = 0.5 , and "negative" or "without attitude" $=0$. Subsequently, conservationist attitudes were also classified into three categories: "negative" (0 to 0.33 ), "moderate" (0.34 to 0.66 ), and "positive" (0.67 to 1.0) (Braga \& Schiavetti 2013). Then, quantitative analyses were performed by the program $\mathrm{R}$ Project for Statistical Computing version 3.3.2 (R Core Team 2016). 


\section{RESULTS}

\section{Profile of fishers}

The fishers interviewed in both estates were men $(n=80)$, with a mean age of over 40 years. The level of schooling is low, with elementary school not completed $(n=55)$ and elementary school completed $(n=16)$. In the four communities, most of the fisher $(n=67)$ have always been active in the fishery, and the others have participated in shrimp fishing for more than 8 years $(n=18)$.

\section{Description of fishing activity}

In all localities the fisher use boats equipped with motor for the fishing of the shrimps. The pattern of this activity is similar in the studied communities, consisting of boats ranging from 5 to $10 \mathrm{~m}$ in length, and crew varying and 1 to 3 per boat. Only one trawling net is used per vessel, and only in Barra Nova are used mechanical winches to gather the trawling nets (Supplementary Material - Table SI).

\section{Local ecological knowledge (LEK) about shrimp (Xiphopenaeus kroyeri)}

In all localities, $X$. kroyeri shrimp is termed "camarão sete-barbas". The LEK information on longevity and shrimp reproduction was not similar to the information in the literature. After the application of the questionnaire, the fishers showed interest in knowing about these biological aspects of the species based on scientific knowledge. The questions that obtained more than $90 \%$ of responses similar to scientific knowledge refer to the growth speed (fast or slow), whether the shrimp are eggs/ larvae at some stage of life, the habitat of the species, and whether the juveniles and adults live in the same region (Table II).

Regarding reproduction, the fisher claim that the female of the shrimp brings the eggs together to the body (after fertilization), and with this, associate the other species of shrimp (Exhippolysmata oplophoroides Holthuis, 1948). This information is not corroborated in the literature, as it is another species. The fisher could not answer the longevity of the Atlantic sea bob shrimp (Table II). On the other hand, these fishers have shown interest in knowing about the biology and ecology of shrimp and are open to dialogue between researchers and the fishing community.

\section{Mean index of conservationist attitudes of the fishers}

The index of all communities studied to evaluate fisher's attitudes toward the conservation of Atlantic seabob shrimp presented a mean of $0.65( \pm 0.04)$, ranging from 0.5 to 0.8 . Most of the interviewees $(n=60)$ presented positive attitudes regarding Atlantic seabob shrimp fishing, and 20 fishers showed moderate attitudes. No fisher's reported fully negative attitudes.

For all fishers interviewed, the period of annual cessation of fishing activity, which is known as the closed season, was important. According to them, this action is important for the conservation of the environment and, consequently, for the Atlantic seabob shrimp, as well as for the maintenance of this fishing resource for future generations.

The negative conservation attitudes regarding shrimp conservation reported by the interviewees relate to the "use of small shrimp", "minimum fishing depths", and bycatch. The fishers report that they can sell the small shrimp mixed with the others, so they profit from all the shrimp caught, regardless of size. This finding was different from what was reported for the bycatch because some items have no commercial value and are thrown back into the sea, such as the following: small fish, for example: porcupinefish (Diontotidae), anchovy (Engraulidae), and grunts (Haemulidae); crustaceans (swimming 
Table Il. Cognitive matrix comparing information among the local ecological knowledge of the fishers and the literature on the biology and ecology of the $X$. kroyeri shrimp.

\begin{tabular}{|c|c|c|}
\hline Questions & Information provided by fishers & Information provided by the scientific literature \\
\hline Folk name & Camarão sete-barbas & $\begin{array}{c}\text { Camarão sete-barbas (Costa et al. 2007, Castilho et al. } \\
\text { 2015). }\end{array}$ \\
\hline \multirow{4}{*}{ Habitat/Migration } & $\begin{array}{l}\text { "This shrimp can be found only } \\
\text { at sea." } \\
\text { "You cannot find it in rivers." }\end{array}$ & $\begin{array}{l}\text { The entire cycle occurs in open sea or in coastal } \\
\text { environments under the influence of saline waters, and it } \\
\text { occurs in bays but never in estuaries (Costa et al. 2003). }\end{array}$ \\
\hline & $\begin{array}{l}\text { "We fished more amounts close to } \\
\text { the coast up to } 20 \text { meters deep." }\end{array}$ & $\begin{array}{l}\text { In general, it lives exclusively in the marine environment } \\
\text { throughout its life cycle, and its greatest abundances are } \\
\text { reported in shallow depths (<30 m) (Silva et al. 2018). }\end{array}$ \\
\hline & $\begin{array}{l}\text { "There are always small and large } \\
\text { shrimp in the same region." }\end{array}$ & $\begin{array}{c}\text { All phases of the life cycle - larvae, juveniles and adults - } \\
\text { occur in the same region in coastal areas, including bays } \\
\text { with salinity above } 30 \text { (Branco 2005). }\end{array}$ \\
\hline & "They stay in the same region." & $\begin{array}{l}\text { The species spends its entire life cycle in the } \\
\text { same environment, and it does not depend on estuaries } \\
\text { for the development of juveniles (Castro et al. 2005). }\end{array}$ \\
\hline \multirow{4}{*}{$\begin{array}{l}\text { Development/ } \\
\text { Longevity }\end{array}$} & $\begin{array}{l}\text { "Fast growth." } \\
\text { "Today, it is small; tomorrow, it } \\
\text { may be large" }\end{array}$ & $\begin{array}{c}\text { Rapid growth (Flores-Hernandéz et al. 2006, Fernandes et } \\
\text { al. 2011, Heckler et al. 2013). }\end{array}$ \\
\hline & "They have eggs." & $\begin{array}{c}\text { During their life cycle, the shrimp go through a larval } \\
\text { phase (eggs) (Dall et al. 1990). }\end{array}$ \\
\hline & $\begin{array}{l}\text { "Females carry the eggs." } \\
\text { "There are times when we only } \\
\text { catch females with eggs." }\end{array}$ & $\begin{array}{l}\text { In Dendrobranchiata, female shrimp release the eggs } \\
\text { directly into the water (Costa et al. 2003). }\end{array}$ \\
\hline & Lack of information & $\begin{array}{c}\text { Longevity is approximately } 18 \text { months (Neiva \& Wise 1963, } \\
\text { Anger 2001, Reis et al. 2017, Silva et al. 2018). }\end{array}$ \\
\hline $\begin{array}{l}\text { Reproduction/ } \\
\text { Recruitment }\end{array}$ & $\begin{array}{c}\text { "Reproduces year-round." } \\
\text { "Here, it is small; on the bottom } \\
\text { or in another place, it can be } \\
\text { large." } \\
\text { "There are always small and } \\
\text { large." }\end{array}$ & $\begin{array}{c}\text { Advanced maturation females are found year-round in } \\
\text { Brazil (Castro et al. 2005, Martins et al. 2013). }\end{array}$ \\
\hline Predator & “Small fish." & Small fish (Camargo \& Isaac 2004). \\
\hline Prey & "Algae, moss, or similar." & $\begin{array}{l}\text { Benthic microalgae, organic matter, feeding on both } \\
\text { benthic animals and primary food sources (Branco \& } \\
\text { Moritz-Junior 2001, Willems et al. 2016). }\end{array}$ \\
\hline
\end{tabular}


crab; Portunidae), jellyfish, trash (anthropic), and debris. The bycatch, which is unloaded and sold as a mixture, comprises small fish: for example: weakfish (Scianidae), Brazilian flounder (Paralichthyidae), marine catfish (Aridae), anchovy (Engraulidae), ray (Rajiformes), "cangoá" (Stardrum; Scianidae), and king croaker (Scianidae).

Regarding the depth, fishers report that shrimp are more likely to be caught close to the shore (approximately 5-m deep) because less fuel is consumed, consequently increasing the profit in the fishery.

\section{Attitudes toward conservation index among fisher villages}

The mean indicator for assessing fisher's attitudes toward shrimp conservation was "positive" in the communities of Barra de Caravelas and Barra Nova, with values of 0.71 and 0.68 , respectively, whereas the attitudes were considered "moderate", with values of 0.63 to 0.65 , respectively, in Anchieta and Santa Cruz Cabrália (Figure 2).

\section{DISCUSSION}

The fisher involved in the $X$. kroyeri shrimp fishery in the studied regions present a social profile similar to that of small-scale fishers in Brazil, and they are characterized as middleaged male workers with a low level of education (Carvalho et al. 2016, Awabdi et al. 2018). These workers become involved with fishing activities very early, mainly to help the family financially, thus dropping out of studies when they were still young (Alencar \& Maia 2011). This scenario may influence the capacity for an effective social organization of fisher and contribute to

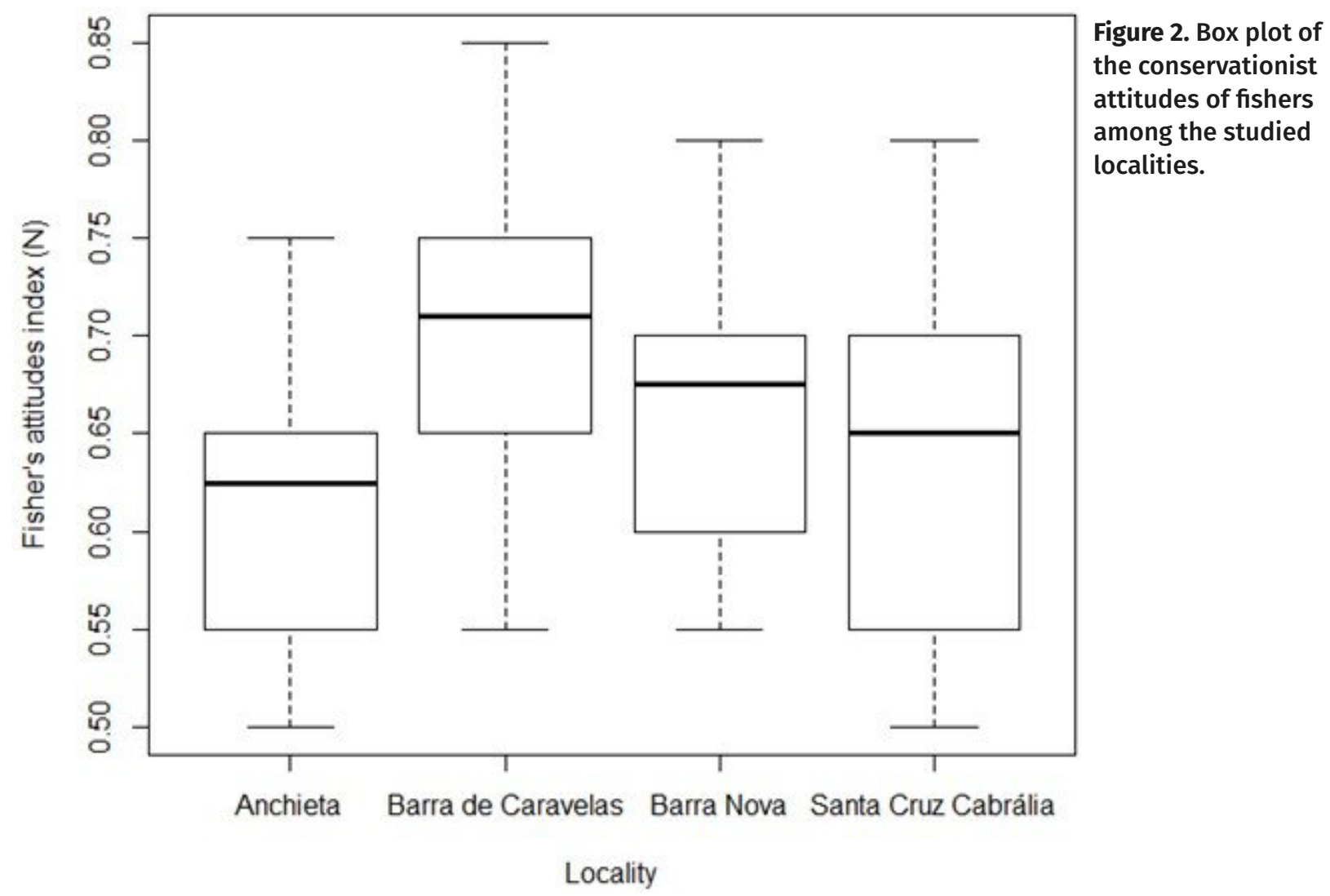


the limited participation of the fisher in the elaboration of fisheries management measures (Romeo \& Marciano 2019).

In all studied communities, fishers (100\%) recognize $X$. kroyeri as being "camarão setebarbas" (folk name), as it in some regions along the Brazilian coast (Castro et al. 2005, Fernandes et al. 2011), or they may be called 'espigudo' as identified by Nascimento et al. (2018) in northeastern Brazil. In other regions of the world, the popular name is 'Atlantic seabob' shrimp (Willems et al. 2016). In Brazil, the name changes mainly during the production chain, according to the type of beneficiation, which can affect the final marketing value by as much as $100 \%$, improving the earnings of the fishers and can, reduce the strong fishing pressure (Pinnegar et al. 2006, Gasalla \& Gandini 2016). The shrimp can be beneficed in 2 forms: i) "crazy" or headless: when remove the head of the shrimp; ii) fillet: when remove the head and peel the shrimp (Musiello-Fernandes et al. 2018). In artisanal fisheries the shrimp businesses are based on an informal economy, and the beneficiation occurs in the family environment, mainly by the wives of the fishers, suggesting that this production activity is not only economically but also culturally important (Teh et al. 2011, Urquhart et al. 2014).

Studies with this social group have demonstrated that small-scale fishers apply LEK in their daily resource exploration practices and have relevant knowledge about the biology and ecology of fishery resources in their region (Silvano \& Begossi 2012, Lima et al. 2018, Medeiros et al. 2018). The combination of this source of information with academic knowledge can result in more assertive management practices, as well as may create new hypotheses of studies, changing the scientific knowledge (Zappes et al. 2013).
At the same time, fishers showed interest in knowing about the biology and ecology of $X$. kroyeri shrimp. Local stakeholders are interested in obtaining technical information about the resource; in addition, the interviewees showed through their discourse the need for education programs to disseminate scientific knowledge in the fishing communities. In some cases, traditional communities do not feel part of the scientific research conducted in their territories (Abreu et al. 2017). This exchange of knowledge tends to minimize this feeling and can be an important step toward improving the relationship between researchers and traditional communities (Chuenpagdee et al. 2013). A lack of local participation and feedback from research to the communities may hinder access to future research, just as it did in New Zealand, where the researcher access to traditional communities was restricted (Mauro \& Hardison 2000).

The shrimp artisanal trawling in Brazil is still marked by conflicts in management, with the fisher's dissatisfaction being intensified mainly by the absence of effective participation in the management process (Silva et al. 2013, Portella \& Medeiros 2016). The dialogue between scientific and traditional knowledge is an important link in the joint search for effective solutions to socioenvironmental problems (Abreu et al. 2017). The inclusion of fishers LEK in fishery management in coastal regions has been successful, allowing for a holistic assessment of the management process, with reduced conflict over fisheries resources in fishing communities in Indonesia, the Philippines, Thailand, Vietnam, and Mexico (Pomeroy et al. 2007, Espinoza-Tenorio et al. 2013). Other examples confirm the benefit of LEK in management, as Maine lobster fishers (New England) have been able to politically and formally activate some state-sanctioned regulations for controlling the lobster fishery (Acheson 2003). 
Fishers reported that the distribution of $x$. kroyeri shrimp is restricted to the marine environment near the coastal region, where young adult shrimp remain in the same region and do not inhabit deep water. However, according to those interviewed, the Atlantic seabob shrimp is never caught within the river, unlike others shrimp, such as white shrimp Litopenaeus schmitti (Burkenroad, 1936). This information is similar to the scientific literature and indicates that the species is distributed in the coastal region with higher biomass between 5 and 35 m (Costa et al. 2003, Graça-Lopes et al. 2007). The species $X$. kroyeri does not present population stratification, completing the life cycle in the coastal region, which is different from what occurs with other shrimp species of the Penaeidae family (Castro et al. 2005).

In the fisher's perception, $X$. kroyeri shrimp is an abundant resource in the marine environment and has a high rate of reproduction and rapid growth. As with the other penaeid shrimp, the fertility rate is high, reaching up to $1,000,000$ (1 million) eggs per reproductive act (PérezFarfante 1936). The life cycle lasts approximately 18 months, indicating rapid growth for the species (Campos et al. 2011).

The LEK of the fisher's indicates that in the first stages of life, the Atlantic seabob shrimp go through only one phase of eggs (or larvae) before being juveniles and later adults. This answer suggests the fisher do not distinguish all stages of life, since penaeid shrimps present three larval phases (nauplii, zoea and misis), a period called post-larva (megalopa), and later, a juvenile phase and an adult phase (Dall et al. 1990). The LEK referring to the life stages of the species does not corroborate with the scientific literature because life cycle analysis requires microscopic equipment to observe some stages (Lopes et al. 2017); and, in this case according to
Hunn (1999), since it has no specific names, it is presumed it has no specific meaning.

For the fisher's interviewed, the females of $X$. kroyeri carry the eggs after fertilization. Such knowledge differs from the literature because shrimp of the Penaeidae family do not carry the fertilized eggs in the body. Such reproduction occurs with Caridean shrimps and may be associated with the species Exhippolysmata oplophoroides (Holthuis 1948), belonging to the Hippolytidae family, which inhabits regions similar to those of the $X$. kroyeri shrimp (Costa et al. 2003). This discrepancy may influence the decision of the fisher when choosing the ideal period for the closure of the shrimp season, as they relate the abundance of another species of shrimp to the reproductive period of the $X$. kroyeri shrimp. Thus, in several regions of Brazil, fishers are opposed to the closed season of shrimp, which undermines the effectiveness of the fisheries management measures (Vasques \& Couto 2011, Musiello-Fernandes et al. 2017).

Fishers report that the $X$. kroyeri shrimp reproduce throughout the year, which is similar to the information reported in the literature, since studies have shown some peaks during the year that vary among regions (Silva et al. 2018). The reproductive period of the species is also another point that can lead to fisher's dissatisfaction regarding the establishment of the closed season. This pattern of reproductive activity for a fishing resource that occurs throughout the year, together with the variations resulting from local environmental conditions, can pose a challenge to the development of management strategies. Consequently, fishers may be dissatisfied because of the difference between the scientific studies and the observed reality (Martins et al. 2013).

Individual attitudes toward nature can both benefit and impair the quality of a particular resource and/or ecosystem because 
these attitudes are a key to achieving the conservation objectives that can contribute to the development of specific actions (Marchini \& Macdonald 2012).

Attitude indices on $X$. kroyeri shrimp conservation of fisher's showed a "moderate" to "positive" trend, whereas no fisher showed a "negative" attitude. The communities studied have small-scale shrimp fishing as an important source of income and subsistence, and thus, these communities present a behavior of positive attitudes for the conservation of this fishery resource. This conservation attitude is similar to that of the European sardine fisher in a fishing community near the Marine Natural Reserve (MNR) of Berlengas (Braga et al. 2017).

In two tropical fisher villages, attitudes toward conservation of marine species were moderate in other studies (Braga \& Schiavetti 2013, Braga et al 2018), as occurred in two communities in this study. Another factor that may interfere with this scenario is the inclusion of the $X$. kroyeri shrimp on the national list of "Overexploited Invertebrates or Threatened by Overexploitation" (MMA 2004). A similar situation has occurred with small-scale fisher in Costa Rica, who recognized the decline in shark fishing and now tends to support measures and show positive attitudes toward the conservation of these animals (O'Bryhim et al. 2016).

Positive attitudes toward species conservation is also observed for other animal groups around the world, e.g., primate species in Southwest China (Ellwanger et al. 2015), elephants in Northern Congo (Nsonsi et al. 2017), and wildlife (elephants, hippopotamus, and antelopes) in Southern Mozambique (de Boer \& Baquete 1998).

In this sense, we suggest environmental education programs in communities with lower indices (Anchieta and Santa Cruz Cabrália) to improve attitudes toward the conservation of
X. Rroyeri shrimp. Environmental education programs can improve attitudes toward the conservation of fishery resources (Daoutopoulos \& Pyrovetsi 1990). Fishers' who are more knowledgeable about the marine environment seem prone to act in accordance with fisheries legislation, as well as to understand the importance of the environment to the fishery resource.

The regions of Barra de Caravelas and Barra Nova presented attitudes classified as "positive," with Barra de Caravelas having the highest index among the studied localities. This community also has the highest LEK index. One reason for this result may be the location of this community in the Extractive Reserve (RESEX) of Cassurubá. In Brazil, the modality of the Sustainable Use Conservation Unit is one of the few instruments available with the possibility of a participatory construction for the shared management of fishery resources (Silva 2004). The RESEX of Cassurubá was created in 2009, and in recent years, greater adhesion and gradual increases have been observed in the participation of the local society in government deliberations, and although room exists for improvement, important advances have been achieved in the construction of instruments for fisheries management (Nobre \& Schiavetti 2013, Nobre et al. 2017).

\section{CONCLUSION}

The $X$. kroyeri shrimp fisheries are a target important source of income and food security for many traditional Western Atlantic communities. On other hand, this ethnoecological study is the first to assess local ecological knowledge (LEK) and attitudes toward conservation of a species. The information's about the LEK and attitudes shared in this study can be very important 
to the formulation and implementation of policies and regulations that take local fishing communities and fishermen into account, and accountable cooperation between local and national governmental authorities.

The fishers report similar information to that of the literature on the habitats, development, and trophic ecology of the $x$. kroyeri shrimp, and can actively contribute to the management process. Regarding conservation attitudes, the Barra de Caravelas region presented the highest index and that result may be associated with the history of information exchange among the stakeholders in the management of the Cassurubá Extractivist Reserve. Moreover, this fact indicates that a positive effect on the dialogue between fishermen and managers of the Cassurubá Extractive Reserve. Therefore, education activities should be conducted in those communities that presented the lower indices (Anchieta and Santa Cruz Cabrália). Education activities and dialogue between fishers and managers should focus on the reproductive aspects of shrimp biology to include fishing communities in the drafting of legislation about closed season period, as this issue is directly related to possible divergences in fishers do not adhere to them.

The positive aspect is that fishers showed an interest in learning the technical knowledge about the shrimp, and the LEK proves to be a way to acquire information about the environment quickly and inexpensively. Finally, the results suggest that, to obtain the efficacy of management measures for the conservation of the $X$. kroyerishrimp resource in the communities studied, dialogue and knowledge exchange is necessary among the stakeholders, including the fisher, scientists and managers, who are responsible for the elaboration of management measures.

\section{Acknowledgments}

The authors thank the fisher, mainly representing the fisher involved in the research, as well as the help location guides in the execution of the data collection. This work is part of the doctoral of first author, who thanks the financial support of the FAPES, Fundação de Amparo à Pesquisa do Espírito Santo/FAPES (Doctoral Grant No. 70839743/15) and CAPES (postdoctoral fellowship; finance code 001). The second authors is grateful to the Fundação Carlos Chagas Filho de Apoio à Pesquisa do Estado do Rio de Janeiro/FAPERJ (E-26/ 203.202/2016 and E-26/202.789/2019) and Conselho Nacional de Desenvolvimento Científico e Tecnológico/ CNPq (Process 400053/2016-0). The third author thanks CAPES (EX: 8926/13-1).

\section{REFERENCES}

ABARCA-ARENAS LG, FRANCO-LOPEZ J, PETERSON MS, BROWNPETERSON NJ \& VALERO-PACHECO E. 2007. Sociometric analysis of the role of penaeids in the continental shelf food web off Veracruz, Mexico based on by-catch. Fish Res 87: 46-57.

ABREU JS, DOMIT C \& ZAPPES CA. 2017. Is there dialogue between researchers and traditional community members? The importance of integration between traditional knowledge and scientific knowledge to coastal management. Ocean Coast Manag 141: 10-19. doi. org/10.1016/j.ocecoaman.2017.03.003.

ACHESON JM. 2003. Capturing the Commons: Devising Institutions to Manage the Maine Lobster Industry. Upne.

ALBUQUERQUE UP, LUCENA R \& ALENCAR N. 2010. Métodos e técnicas para coleta de dados etnobiológicos. In: Albuquerque UP et al. (Eds), Métodos e técnicas na pesquisa etnobiológica e etnoecológica. Recife: NUPPEA, Recife, BR, p. 39-64.

ALBUQUERQUE UP, LUCENA, RF, CUNHA LV \& ALVES RRN. 2014. Methods and Techniques in Ethnobiology and Ethnoecology. Springer, New York, 358 p.

ALENCAR CAG \& MAIA LP. 2011. Perfil Socioeconômico dos pescadores brasileiros. Arq Cienc Mar 44: 12-19.

ALLISON H \& ELLIS F. 2001. The livelihoods approach and management of small-scale fisheries. Mar Policy 25: 377388. http://dx.doi.org/10.1016/S0308-597X(01)00023-9.

ANGER K. 2001. The biology of decapod crustacean larvae: Crustacean. Balkema Publishers, 419 p. 
ARAUJO LG, CASTRO VF, DE FREITAS RR \& SEIXAS CS. 2017. Struggles for inclusive development in small-scale fisheries in Paraty. Ocean Coast Manage 150: 24-34.

AWABDI DR, TAVARES DC, BONDIOLI ACV, ZAPPES CA \& DI BENEDITTO APM. 2018. Influences of conservation action on attitudes and knowledge of fisher towards sea turtles along the southeastern Brazil. Mar Policy 95: 57-68. https://doi.org/10.1016/j.marpol.2018.06.024.

AZEVEDO CM. 2005. A regulamentação do acesso aos recursos genéticos e aos conhecimentos tradicionais associados no Brasil. Biota Neotrop 5: 1-9.

BAYLEY KD. 1982. Methods of Social Research, second ed., The Free Press Macmillan Publishers, Nova York, 553 p.

BATISTA VS, FABRÉ NN, MALHADO ACM \& LADLE RJ. 2014. Tropical Artisanal coastal fisheries: challenges and future directions. Rev Fish Sci Aquac 22: 1-15.

BEGOSSI A. 2006. The ethnoecology of Caiçara metapopulations (Atlantic Forest, Brazil): ecological concepts and questions. J Ethnobiol Ethnomed 2: 40-51.

BEGOSSI A. 2008. Local knowledge and training towards management. Environ Dev Sustain 10: 591-603. https:// doi.org/10.1007/s10668-008-9150-7.

BERKES F. 1999. Sacred Ecology: Traditional Ecological Knowledge and Resource Management, fourth ed. Taylor and Francis, Philadelphia, 568 p.

BERKES F, MAHON R, MCCONNEY P, POLLNAC RB \& POMEROY R. 2001. Managing Small-Scale Fisheries: Alternative Directions and Methods, IRDC, first ed., Ottawa, 250 p.

BRAGA HDO \& SCHIAVETTI A. 2013. Attitudes and local ecological knowledge of experts fisher in relation to conservation and bycatch of sea turtles (reptilia: testudines), Southern Bahia, Brazil. J Ethnobiol Ethnomed 9: 15-23. https://doi.org/10.1186/1746-4269-9-15.

BRAGA HO, AZEITEIRO UM, OLIVEIRA HMF \& PARDAL MA. 2017. Evaluating fishermen's conservation attitudes and local ecological knowledge of the European sardine (Sardina pilchardus), Peniche, Portugal. J Ethnobiol Ethnomed 13: 1-12. https://doi.org/10.1186/s13002-017-0154-y.

BRAGA HO, AZEITEIRO UM, OLIVEIRA HMF \& PARDAL MA. 2018. Conserving Brazilian Sardine: Fisher's attitudes and knowledge in the Marine Extractive Reserve of Arraial do Cabo, Rio de Janeiro State, Brazil. Fish Res 204: 402-411. https://doi.org/10.1016/j.fishres.2018.03.019.

BRANCO JO. 2005. Biologia e pesca do camarão setebarbas Xiphopenaeus kroyeri (Heller, 1862) (Crustacea, Penaeidae), na Armação do Itapocoroy, Penha, Santa Catarina. Brasil. Rev Bras Zool 22: 1050-1062.
BRANCO JO \& MORITZ-JUNIOR HC. 2001. Natural feeding of Xiphopenaeus kroyeri (Heller) (Crustacea, Decapoda) in the Armação do Itapocoroy, Penha Santa Catarina. Rev Bras Zool 18: 53-61.

CAMARGO M \& ISAACV. 2004. Food categories reconstruction and feeding consumption estimates for the Sciaenid Macrodon ancylodon (Bloch \& Schneider), and the congeneric fishes Stellifer rastrifer (Jordan) and Stellifer naso (Jordan) (Pisces, Perciformes) in the Caeté Estuary, Northern Coast of Brazil. Rev Bras Zoo 21: 85-89.

CAMPOS BR, BRANCO JO \& D'INCAO F. 2011. Crescimento do Camarão-Sete-Barbas (Xiphopenaeus kroyeri (Heller 1862)), Na Baía de Tijucas, Tijucas, SC (Brasil). Atlântica 33: 201-208. hhttps://doi.org/ 10.5088/atl.2011.33.2.201.

CARVALHO R, NAMEDE N, ROCHA BR \& SOUSA B. 2016. Attitudes towards conservation and fishing interaction with sea turtles in the southeast coast of Brazil. Ocean Coast Manage 127: 55-62. http://dx.doi.org/10.1016/j.oceco aman.2016.04.011.

CASTILHO AL, BAUER RT, FREIRE FAM, FRANSOZO V, COSTA RC, GRABOWSKI RC \& FRANSOZO A. 2015. Lifespan and reproductive dynamics of the commercially important sea bob shrimp Xiphopenaeus kroyeri (Penaeoidea): synthesis of a 5-year study. J Crustacean Biol 35: 30-40. https://doi.org/10.1163/1937240X-00002300.

CASTRO RH, COSTA RC, FRANSOZO A \& MANTELATTO FLM. 2005. Population structure of seabob shrimp Xiphopenaeus kroyeri (Heller, 1862) (Crustacea: Penaeoidea) in the littoral of São Paulo, Brazil. Sci Mar 69: 105-112.

CHUENPAGDEE R, PASCUAL-FERNANDEZ J, SZELIANSZKY EJ, ALERGRET L, FRAGA J \& JENTOFT S. 2013. Marine protected areas: Re-thinking their inception. Mar Policy 39: 234-240.

COSTA RC, FRANSOZO A, FREIRE FAM \& CASTILHO AL. 2007. Abundance and ecological distribution of the "setebarbas" shrimp Xiphopenaeus kroyeri (Heller, 1862) (Decapoda, Penaeoidae) in the three bays of de Ubatuba region, south-eastern Brazil. Gulf Carib Res 19: 33-41.

COSTA RC, FRANSOZO A, MELO GM \& FREIRE FAM. 2003. Chave ilustrada para a identificação dos camarões dendrobranchiata do litoral norte de São Paulo, Brasil. Biota Neotropica 3: 1-12.

CROUCH M \& MCKENZIE H. 2006. The logic of small samples in interview-based qualitative research. Soc Sci Inf 45: 483-499.

DALL W, HILL BJ, ROTHLISBERG PC \& SHARPLES DJ. 1990. The biology of the 559 Penaeidae. Adv Mar Biol 27: 1-489.

DAOUTOPOULOS GA \& PYROVETSI M. 1990. Comparison of conservation attitudes among fisher in three protected 
lakes in Greece. J Environ Manage 31: 83-92. doi: 10.1016/ S0301-479780016-7.

DE BOER WF \& BAQUETE DS. 1998. Natural resource use, crop damage and attitudes of rural people in the vicinity of the Maputo Elephant Reserve, Mozambique. Environ Conserv 25: 208-218.

DEEPANANDA AKHM, AMARASINGHE US, JAYASINGHE-MUDALIGE UK \& BERKES F. 2016. Stilt Fisher knowledge in southern Sri Lanka as an expert system: a strategy towards comanagement. Fish Res 174: 288-297.

EAGLY AH \& CHAIKEN S. 1993. The psychology of attitudes. Ft. Worth: Harcourt Brace Jovanovich College Publishers.

ELLWANGER AL, RILEY EP, NIU K \& TAN CL. 2015. Local People's Knowledge and Attitudes Matter for the Future Conservation of the Endangered Guizhou Snub-Nosed Monkey (Rhinopithecus brelichi) in Fanjingshan National Nature Reserve, China. Int J Primatol 36: 33-54.

ESPINOZA-TENORIO A, WOLFF MI, ESPEJEL G \& MONTAÑOMOCTEZUMA. 2013. Using traditional ecological knowledge to improve holistic fisheries management: transdisciplinary modeling of a lagoon ecosystem of southern Mexico. Ecol Soc 18: 6-15.

FAO. 2012. The State of World Fisheries and Aquaculture. Rome: FAO Fisheries and Aquaculture Department.

FERNANDES LP, SILVA AC, JARDIM LP, KEUNECKE KA \& DI BENEDITTO APM. 2011. Growth and recruitment of the Atlantic seabob shrimp, Xiphopenaeus kroyeri (Heller, 1862) (Decapoda, Penaeidae), on the coast of Rio de Janeiro, southeastern Brazil. Crustaceana 84: 1465-1480.

FINKBEINER EM. 2015. The role of diversification in dynamic small-scale fisheries: les-sons from Baja California Sur, Mexico. Global Environ 32: 139-152.

FLORES-HERNANDÉZ D, MIRANDA RJ \& CRIOLLO FG. 2006. Evaluación de la pesquería de camarón siete barbas (Xiphopenaeus kroyeri) em el sur del Golfo de México. Bol Inf Jaina 16: 61-66.

FOSTER SJ \& VINCENT ACJ. 2010. Tropical shrimp trawl fisheries: fishers' knowledge of and attitudes about a doomed fishery. Mar Policy 34: 437-446.

GASALLA MA \& GANDINI FC. 2016. The loss of fishing territories in coastal areas: the case of seabob-shrimp small-scale fisheries in São Paulo, Brazil. Marit Studies 15: 9-8.

GRAÇA-LOPES R, SANTOS EP, SEVERINO-RODRIGUES E, BRAGA FMS \& PUZZ A. 2007. Aportes ao conhecimento da biologia e da pesca do camarão sete barbas (Xiphopenaeus kroyeri Heller, 1862) no litoral do estado de São Paulo, Brasil. Bol Inst Pesca 33: 63-84.

HARRIS M. 1976. History and significance of the emic/etic distinction. Annu Rev Anthropol 5: 329-350. doi: 10.1146/ annurev.an.05.100176.001553.

HAWKINS JP \& ROBERTS CM. 2004. Effects of artisanal fishing on Caribbean Coral Reefs. Conserv Biol. 18: 215-226. http://dx.doi.org/10.1111/j.1523-1739.2004.00328.x.

HECKLER GS, SIMÕES SM, SANTOS APF, FRANSOZO A \& COSTA RC. 2013. Population dynamics of the seabob shrimp Xiphopenaeus kroyeri (Dendrobranchiata, Penaeidae) in south-eastern Brazil. Afr J Mar Sci 35: 17-24. doi: 10.2989/1814232X.2013.769901.

HOEHN S \& THAPA B. 2009. Attitudes and perceptions of indigenous fisher towards marine resource management in Kuna Yala, Panama. Int J Sust Dev World 16: 427-437.

HUNN E. 1999. Size as limiting the recognition of biodiversity in folk biological classifications: One of four factors governing the cultural recognition of biological taxa. Folk Biology 4: 47-69.

HYNES S, NORTON D \& CORLESS R. 2014. Investigating societal attitudes towards the marine environment of Ireland. Mar Policy 47: 57-65. https://doi.org/10.1016/j. marpol.2014.02.002.

ICMBIO - INSTITUTO CHICO MENDES. 2012. Instrução Normativa № 29, de 05 de setembro de 2012. Disciplina, no âmbito do Instituto Chico Mendes, as diretrizes, requisitos e procedimentos administrativos para a elaboração e aprovação de Acordo de Gestão em Unidade de Conservação de Uso Sustentável federal com populações tradicionais. Diário da União 69. Brasília, no 175.

LEÃO ZM, KIKUCHI RK \& TESTA V. 2003. Corals and coral reefs of Brazil. In: Cortés J (Ed), Latin American Coral Reefs, Amsterdam: Elsevier, Amsterdam, p. 9-52.

LEITE M \& GASALLA MA. 2013. A method for assessing Fishers' ecological knowledge as a practical tool for ecosystembased fisheries management: seeking consensus in Southeastern Brazil. Fish Res 145: 43-53.

LIKERT R. 1932. A technique for the measurement of attitudes. Arch Psychol 22: 55-69.

LIMA JS, ZAPPES CA, DI BENEDITTO APM \& ZALMON IR. 2018. Artisanal fisheries and artificial reefs on the southeast coast of Brazil: Contributions to research and management. Ocean Coast Manag 163: 372-382. doi. org/10. 1016/j.ocecoaman.2018.07.018. 
LOPES DFC, FRÉDOU FL, BEZERRA E, CALAZANS N \& PEIXOTO S. 2017. Reproductive cycle of seabob shrimp Xiphopenaeus kroyeri (Crustacea, Penaeidea) from the northeast coast of Brazil. Invertebr Reprod Dev 1: 1-5. https://doi.org/10.1 080/07924259.2017.1311951.

MAHON R. 1997. Does fisheries science serve the needs of managers of small stocks in developing countries? Can J Fish Aquat Sci 54: 2207-2213.

MALINOWSKI BK. 1978. Os pensadores: Argonautas do Pacífico Ocidental: Um relato do empreendimento e da aventura dos nativos nos Arquipélagos da Nova Guiné Melanésia. Abril Cultural, São Paulo, 672 p.

MARCHINI S \& MACDONALD DW. 2012. Predicting ranchers' intention to kill jaguars: Case studies in Amazonia and Pantanal. Biol Conserv 147: 213-221.

MARTINS AS, PINHEIRO HT \& LEITE JÚNIOR NO. 2013. Biologia reprodutiva do camarão sete-barbas no centro sul e sul do Espírito Santo, Brasil. Bol Inst Pesca 39: 205-215.

MASON M. 2010. Sample size and saturation in PhD studies using qualitative interviews. Forum Qual. Soz./Forum: Qual Soc Res 11(3): 1-19. 〈http://www.qualitativeresearch. net/index.php/fqs/article/view/1428〉.

MAURO F \& HARDISON PD. 2000. Traditional knowledge of indigenous and local communities: International debate and policy initiatives. Ecol Appl 10: 1263-1269.

MEDEIROS MC, BARBOZA RRD, MARTEL G \& MOURÃO JS. 2018. Combining local fishers' and scientific ecological knowledge: Implications for co management. Ocean Coast Manag 185: 1-10. https://doi.org/10.1016/j. ocecoaman.2018. 03.014.

MILFONT T L \& DUCKITT J. 2010. The environmental attitudes inventory: A valid and reliable measure to assess the structure of environmental attitudes. J Environ Psychol 30: 80-94.

MMA - MINISTÉRIO DO MEIO AMBIENTE. 2004. Reconhece como espécies ameaçadas de extinção e espécies sobreexplotadas ou ameaçadas de sobreexplotação os invertebrados aquáticos e peixes. Brasília, Brasil.

MMA - MINISTÉRIO DO MEIO AMBIENTE. 2014. Lista Nacional Oficial de Espécies da Fauna Ameaçadas de Extinção Peixes e Invertebrados Aquáticos. Brasília, Brasil.

MUSIELLO-FERNANDES J, ZAPPES CA \& HOSTIM-SILVA M. 2017. Small-scale shrimp fisheries on the Brazilian coast: stakeholders' perceptions of the closed season and integrated management. Ocean Coast Manag 148: 89-96. http://dx.doi.org/10.1016/j.ocec oaman.2017.07.018.
MUSIELLO-FERNANDES J, ZAPPES CA \& HOSTIM-SILVA M. 2018. Small-scale fisheries of the Atlantic seabob shrimp (Xiphopenaeus kroyeri): Continuity of commercialization and maintenance of the local culture through making public policies on the Brazilian coast. Ocean Coast Manag 155: 76-82. https://doi.org/10.1016/j. ocecoaman.2018.01.033.

NASCIMENTO GCC, CÓRDULA EBL, SILVEIRA TMA \& SILVA MCBC. 2018. Conhecimento etnoecológico na pesca artesanal do camarão marinho (Penaeidae): sinergia dos saberes. Ethnoscientia 3: 1-18.

NEIVA GS \& WISE JP. 1963. The biology and fishery of the sea bob shrimp of Santos Bay, Brazil. Proc Gulf Caribb Fish Inst 16: 131-139.

NOBRE DM, ALARCON DT, CINTI A \& SCHIAVETTI A. 2017. Governance of the Cassurubá Extractive Reserve, Bahia State, Brazil: An analysis of strengths and weaknesses to inform policy. Mar Policy 77: 44-55. http://dx.doi. org/10.1016/j.marpol.2016.12.008.

NOBRE DM \& SCHIAVETTI A. 2013. Acordos de Pesca, Governança e Conselho Deliberativo de Reserva Extrativista: Caso da Resex de Cassurubá, Caravelas, Bahia, Brasil. Bol Inst Pesca 39: 445-455.

NSONSI F, HEYMANS J-C, DIAMOUANGANA J \& BREUER T. 2017. Attitudes Towards Forest Elephant Conservation Around a Protected Area in Northern Congo. Conserv Soc 15: 5973. http://dx.doi.org/10.4103/0972-4923.201394.

O'BRYHIM JR, PARSONS ECM, GILMORE MP \& LANCE SL. 2016. Evaluating support for shark conservation among artisanal fishing communities in Costa Rica. Mar Policy 71: 1-9. http://dx.doi.org/10.1016/j.marpol.2016.05.005.

OLIVEIRA JÚNIOR JGC, SILVA LPS, MALHADO ACM, BATISTA VS, FABRÉ NN \& LADLE RJ. 2016. Artisanal Fisheries Research: A Need for Globalization? PLoS ONE 11: 1-10.

OLSSON P \& FOLKE C. 2001. Local ecological knowledge and institutional dynamics for ecosystem management: a study of Lake Racken watershed, Sweden. Ecosystems 4: 85-104.

OPDENAKKER R. 2006. Advantages and disadvantages of four interview techniques in qualitative research. Forum Qual. Sozial Schung/Forum Qual Soc Res 7. http://nbnresolving.de/urn:nbn:de:0114-fqs0604118.

PATTON MQ. 1990. Qualitative Evaluation and Research Methods, Publications, Newbury Park, 532 p.

PAULY D. 2006. Major trends in small-scale marine fisheries, with emphasis on developing countries, and some implications for the social sciences. Marit Stud 4: $7-22$. 
PÉREZ-FARFANTE I. 1936. Sinopsis de dados sobre el camaron blanco Penaeus schmitti Burkenroad, 1936. FAO Fish. Rep. № 37 :1.417-1.438, 1970.

PINNEGAR JK, HUTTON TP \& PLACENTI V. 2006. What relative seafood prices can tell us about the status of stocks. Fish Fish 7: 219-226. doi: 10.1111/j.1467-2979.2006.00219.x.

PITA C, PIERCE GJ \& THEODOSSIOU I. 2010. Stakeholders' participation in the fisheries management decisionmaking process: fishers' perceptions of participation, Mar Policy 34: 1093-1102. https://doi.org/10.1016/j. marpol.2010.03.009.

POMEROY R, PARKS J, POLLNAC R. CAMPSON T, GENIO E, MARLESSY C, HOLLE E, PIDO M, NISSAPA A, BOROMTHANARAT S \& THU-HUE N. 2007. Fish wars: conflict and collaboration in fisheries management in Southeast Asia. Mar Policy 31: 645-656.

PORTELLA GGD \& MEDEIROS RP. 2016. Modificações estruturais nas redes de arrasto de camarão: percepção dos pescadores e implicações para a gestão em uma área marinha protegida. Bol Inst Pesca 42: 1-16.

R CORE TEAM. 2016. A Language and Environment for Statistical Computing, R. Foundation for Statistical Computing, Vienna.

REIS JC, FREIRE K, ROSA L, BARRETO TMRR \& PAULY D. 2017. Population dynamics of Atlantic seabob Xiphopenaeus kroyeri (Decapoda: Penaeidae) off the state of Sergipe, north-eastern Brazil. J Mar Biol Assoc Uk 99: 143-153.

ROMEO G \& MARCIANO C. 2019. Evaluating the economic performance of fishing systems using fuzzy multicriteria analysis in a Fishery Local Action Group in South Italy. Fish Res 218: 259-268. https://doi.org/10.1016/j. fishres.2019.05.015.

SILVA CNS, BROADHURST MK, MEDEIROS RP \& DIAS JH. 2013. Resolving environmental issues in the southern Brazilian artisanal penaeid-trawl fishery through adaptive co management. Mar Policy 42: 133-141.

SILVA PP. 2004. From common property to co-management: lessons from Brazil's first maritime extractive reserve. Mar Policy 28: 419-428.

SILVA SLR, SANTOS R, COSTA R \& HIROSE G. 2018. Growth and population structure of the seabob shrimp Xiphopenaeus kroyeri (Decapoda: Penaeidae) on the continental shelf of Sergipe, Brazil. J Mar Biol Assoc Uk 99: 81-92. https:// doi.org/10.1017/S0025315417002041.

SILVANO RAM \& BEGOSSI A. 2012. Fisher's local ecological knowledge on Southeastern Brazilian coastal fishes: contributions to research, conservation, and management. Neotrop Ichthyol 10: 133-147.
TEH LSL, TEH LCL \& SUMAILA UR. 2011. Quantifying the overlooked socio-economic contribution of small-scale fisheries in Sabah, Malaysia. Fish Res 110: 450-458. doi: 10.1016/j.fishres.2011.06.001.

TONIN S \& LUCARONI G. 2017. Understanding social knowledge, attitudes and perceptions towards marine biodiversity: The case of tegnùe in Italy. Ocean Coast Manag 140: 68-78. https://doi.org/10.1016/j. ocecoaman.2017.02.019.

URQUHART J, ACOTT JG, SYMES D \& ZHA M. 2014. Social Issues in Sustainable Fisheries Management. Springer, London, $374 \mathrm{p}$.

VASQUES ROR \& COUTO ECG. 2011. Percepção dos pescadores quanto ao estabelecimento do período de defeso da pesca de arrasto para a região de Ilhéus (Bahia, Brasil). Rev Gestão Cost Integr 11: 479-485.

VIANA DF, CAMARGO E \& DUTRA GF. 2015. Avaliação econômica da pesca do camarão sete-barbas, Xiphopenaeus kroyeri (Heller, 1862), no município de Caravelas, BA, Brasil. Bol Inst Pesca 41: 419-428.

WATSON RA. 2017. Database of global marine commercial, small-scale, illegal, and unreported fisheries catch 19502014. Nat Sci Data 4: 170039.

WHITE PC, JENNINGS NV, RENWICK AR \& BARKER NH. 2005. Review: questionnaires in ecology: a review of past use and recommendations for best practice. J Appl Ecol 42: 421-430.

WILLEMS T, DE BACKER T A, KERKHOVE T, DAKRIET NN, DE TROCH M, VINCX M \& HOSTENS K. 2016. Trophic ecology of Atlantic seabob shrimp Xiphopenaeus kroyeri: intertidal benthic microalgae support the subtidal food web off Suriname. Estuar Coast Shelf S 182: 146-157.

YEASMIN S \& RAHMAN KF. 2012. 'Triangulation' research method as the tool of social science research. Bup $J 1$ : 154-163.

ZAPPES CA, SILVA CV, PONTALTI M, DANIELSKI ML \& DI BENEDITTO APM. 2013. The conflict between the southern right whale and coastal fisheries on the southern coast of Brazil. Mar Policy 38: 428-437. http://dx.doi.org/10.1016/j. marpol.2012.07.003.

\section{SUPPLEMENTARY MATERIAL}

\section{Table SI.}




\section{How to cite}

MUSIELLO-FERNANDES J, ZAPPES CA, BRAGA HO \& HOSTIM-SILVA M. 2021. Artisanal fishers' local ecological knowledge and attitudes toward conservation about the shrimp (Xiphopenaeus kroyeri) on the Brazilian central coast. An Acad Bras Cienc 93: e20191047. DOI 10.1590/00013765202120191047.

Manuscript received on September 12, 2019;

accepted for publication on November 24, 2019

\section{JOELSON MUSIELLO-FERNANDES ${ }^{1,4}$}

https://orcid.org/0000-0001-6609-4474

CAMILAH A. ZAPPES ${ }^{1,2}$

https://orcid.org/0000-0002-5486-6577

\section{HEITOR O. BRAGA ${ }^{3}$}

https://orcid.org/0000-0002-9627-115X

\section{MAURICIO HOSTIM-SILVA ${ }^{1,4}$}

https://orcid.org/0000-0001-5061-9125

${ }^{1}$ Programa de Pós-Graduação em Oceanografia Ambiental (PPGOAM), Universidade Federal do Espírito Santo, Centro de Ciências Humanas e Naturais (CCHN), Av. Fernando Ferrari, 514, Goiabeiras, 29075-910 Vitória, ES, Brazil ${ }^{2}$ Universidade Federal Fluminense, Instituto de Ciências da Sociedade e Desenvolvimento Regional, Departamento de Geografia, Rua José do Patrocínio, 71, Centro, 28010-385 Campos dos Goytacazes, RJ, Brazil

${ }^{3}$ Department of Biology \& CESAM -Centre for Environmental and Marine Studies, University of Aveiro, 3810-19, Aveiro, Portugal

${ }^{4}$ Universidade Federal do Espírito Santo (UFES), CEUNES, Laboratório de Ecologia de Peixes Marinhos, PPGBT, Rodovia BR 101 Norte, Km 60, Litorâneo, s/n, 29932-540 São Mateus, ES, Brazil

Correspondence to: Joelson Musiello-Fernandes E-mail: joelson.pesca@gmail.com

\section{Author contributions}

Joelson Musiello Fernandes: Responsible for the execution of the research article, conducted the collected, data analysis and wrote the manuscript. Camilah Antunes Zappes and Mauricio Hostim Silva: contributed to orientation, assisting in the execution of the article, data analysis and reviewed the manuscript. Heitor Oliveira Braga: Responsible for assisting in the statistical analysis and reviewed the manuscript.

\section{(cc) BY}

